\title{
Effect of the roselle (Hibiscus sabdariffa L.) calyces drink on the physiological parameters of healthy adult subjects
}

\author{
AJENG DIANTINI ${ }^{1}$, SYAMSUL RAHMAT $^{1,2}$, ANNISA ALPIANI ${ }^{1,3}$, \\ SRI ADI SUMIWI ${ }^{1}$, LEONARDO LUBIS ${ }^{4}$ and JUTTI LEVITA ${ }^{1}$
}

\begin{abstract}
${ }^{1}$ Department of Pharmacology and Clinical Pharmacy, Faculty of Pharmacy, Universitas Padjadjaran, Bandung, West Java 45363; ${ }^{2}$ Faculty of Health, Universitas Qamarul Huda Badaruddin Bagu, Central Lombok Regency, West Nusa Tenggara 83371; ${ }^{3}$ Faculty of Health, Universitas Nahdlatul Ulama, Mataram, West Nusa Tenggara 83123;

${ }^{4}$ Department of Anatomy, Physiology, and Cell Biology, Faculty of Medicine, Universitas Padjadjaran, Bandung, West Java 45363, Indonesia
\end{abstract}

Received July 13, 2021; Accepted August 17, 2021

DOI: 10.3892/br.2021.1465

\begin{abstract}
The calyx of roselle (Hibiscus sabdariffa $\mathrm{L}$.) has been the focus of attention of several studies, and although earlier studies on this plant showed it to possess antilipidemic and antidiabetic activities, none of these studies have assessed the effects of this plant on the physiological parameters of healthy subjects. The present study determined the effects of roselle calyx beverages on blood pressure, abdominal circumference, body mass index (BMI), hematological and urinary parameters, and the lipid profile of healthy subjects. Healthy subjects $(n=30)$ were treated with a $200 \mathrm{ml}$ roselle calyx beverage each morning and evening for 30 consecutive days. Every week the subjects were asked to perform some physical activity by following the Young Men's Christian Association step test. This study used a pre-post quasi-experimental design. Blood samples were taken before (day-0) and after the intervention (day-30). There was an increase in the levels of high-density lipoproteins (from 47.0 to $49.5 \mathrm{mg} / \mathrm{dl} ; \mathrm{P}=0.015$ ), and a significant decrease in both systolic and diastolic $(\mathrm{P}=0.036$ and $\mathrm{P}=0.030$, respectively), and the abdominal circumference of the subjects $(\mathrm{P}=0.005)$. However, total cholesterol levels (191.2 to $191.9 \mathrm{mg} / \mathrm{dl} ; \mathrm{P}=0.821$ ) and low-density lipoprotein levels (129.8 to $133.5 \mathrm{mg} / \mathrm{dl} ; \mathrm{P}=0.249$ ) were slightly increased, although not significantly. A lower level of triglycerides (114.3 to $107.4 \mathrm{mg} / \mathrm{dl} ; \mathrm{P}=0.269$ ) and very-low-density lipoprotein levels ( 22.8 to $21.4 \mathrm{mg} / \mathrm{dl} ; \mathrm{P}=0.681$ ) was observed. No significant differences were detected in the BMI or the urinalysis parameters were identified. Based on these results, roselle
\end{abstract}

Correspondence to: Professor Jutti Levita, Department of Pharmacology and Clinical Pharmacy, Faculty of Pharmacy, Universitas Padjadjaran, Jl. Raya Bandung-Sumedang $\mathrm{km} 21$, Sumedang, West Java 45363, Indonesia

E-mail: jutti.levita@unpad.ac.id

Key words: anthocyanins, antioxidants, flavonoids, Hibiscus sabdariffa, roselle
(Hibiscus sabdariffa L.) may be used as a supplement to prospectively improve the health status of subjects. No serious adverse effects were observed during this trial.

\section{Introduction}

In Asia, particularly Indonesia, the dried calyces of roselle (Hibiscus sabdariffa L.) flower have been commonly utilized as hot and cold beverages. A study of the effect of the dried $H$. sabdariffa calyces extracts in hypertensive rats indicated it possessed antihypertensive activity (1).

A previous randomized-control cross-over study on 25 British male participants with $1-10 \%$ cardiovascular risk disease at the Hugh Sinclair Unit of Human Nutrition (University of Reading, UK), reported that the consumption of 2-meal $H$. sabdariffa calyces extracts increased the flow-mediated dilatation of the branchial artery, urinary and plasma nitric oxide (NOx) levels, and decreased the systolic (SBP) and diastolic blood pressure (DBP), as well as serum glucose, plasma insulin, serum triacylglycerol and C-reactive protein levels (2). A double-blind, placebo-controlled clinical trial revealed that daily consumption of $H$. sabdariffa tisane significantly lowered SBP and DBP in 65 non-smoking adults (70\% Caucasians) recruited from the greater Boston area who were diagnosed with pre to mild hypertension (3). $H$. sabdariffa consumption also significantly lowered plasma angiotensin-converting enzyme activity and serum sodium levels without altering potassium levels in Mexican adult patients with stage I or II hypertension (4). Furthermore, twice daily consumption of $H$. sabdariffa tea in 60 Iranian diabetic patients with mild hypertension in Yazd, Iran, for 1 month resulted in a decrease in SBP, but no effect on DBP (5). A study on 32 African male subjects (aged 21-32) in Cameroon, Central Africa, showed that consuming $500 \mathrm{ml}$ $H$. sabdariffa drink twice a day for 2 weeks resulted in a significant increase in erythrocyte counts, hemoglobin levels, packed cell volume, mean platelet volume, high-density lipoprotein (HDL), triglycerides and creatinine levels, as well as significantly reducing leucocytes counts, MID cells, low-density lipoprotein (LDL) and total cholesterol levels. It 
was reported that there was no significant change in blood glucose, L-aspartate aminotransferase, L-alanine aminotransferase and urea levels (6).

However, none of these studies assessed the effects of $H$. sabdariffa on healthy Indonesian subjects. The present study examined the effects of the $H$. sabdariffa beverage (HSB) on the physiological parameters of healthy Asian male and female subjects. The aim of this study was to: i) Assess hematological and urinary parameters; and ii) measure the lipid profile of healthy Indonesian male and female subjects, after twice daily consumption of HSB for 30 days.

\section{Materials and methods}

Study area. The present study was performed at the Faculty of Pharmacy, Universitas Padjadjaran, and the Health Technical Unit of Universitas Padjadjaran, (West Java, Indonesia) in 2019.

Identification of plant material. Dried roselle (H. sabdariffa) calyces, purchased in Bandung (West Java, Indonesia), were taxonomically identified (document no. 187/05/HB/2018) by Dr Joko Kusmoro, a certified biologist, at the Laboratory of Plant Taxonomy, Department of Biology, Faculty of Mathematics and Natural Sciences, Universitas Padjadjaran.

Preparation of HSB. HSB was prepared by following the boiling method described by Salami and Afolayan (7) with some modifications (without the addition of sliced fruits pineapple, oranges or lime with peel). In total, $100 \mathrm{~g}$ dried calyces were boiled in 101 potable water for $15 \mathrm{~min}$. A small amount of sugar $500 \mathrm{~g} / 101$ was added to neutralize the sourness.

Proximate analysis, and determination of vitamin $C$ and anthocyanins in HSB. Proximate content (moisture, ash, protein, fat and carbohydrates) and vitamin $C$ levels in the HSB were strictly determined according to the protocol of the Indonesian National Standard SNI 01-2891-1992 (8). The determination of anthocyanin content in the HSB was carried out by following the $\mathrm{pH}$ differential method as described by Giusti and Wrolstad (9). This method measures the difference in the absorbance spectra of the colored oxonium form of anthocyanin at $\mathrm{pH} 1.0$ and the colorless hemiketal form at $\mathrm{pH}$ 4.5. The results are presented in Table I.

Subject recruitment and ethical considerations. A total of 30 subjects aged 21-55 (39.33 \pm 9.18$)$ years old, 17 male and 13 female, were recruited by an advertisement spread. The subjects had agreed to participate in the present study by signing the informed consent form according to the Ethical Principles for Medical Research involving Human Subjects of the WMA Declaration ofHelsinki(wma.net/policies-post/wma-declarationof-helsinki-ethical-principles-for-medical-research-involvinghuman-subjects/). All subjects were confirmed healthy (Table II) after being examined by a certified medical practitioner at the Health Technical Unit of Universitas Padjadjaran. The present study was approved by the Research Ethics Committee of Faculty of Medicine, Universitas Padjadjaran (approval no. 35/UN6.C.10/PN/2018; kep.unpad.ac.id/), which is recognized by the FERCAP-Forum of Ethics Review Committee in Asia \& Western Pacific Region, since 2014).
Table I. Nutritional properties of HSB.

\begin{tabular}{lrl}
\hline Constituent & Result & \multicolumn{1}{c}{ Method $^{\mathrm{a}}$} \\
\hline Water, \% & 94.82 & SNI 01-2891-1992 \\
Ash, \% & 0.09 & SNI 01-2891-1992 \\
Protein, \% & 0.28 & SNI 01-2891-1992 \\
Fat, \% & 1.47 & SNI 01-2891-1992 \\
Carbohydrate, \% & 3.34 & SNI 01-2891-1992 \\
Vitamin C, \% & 0.02 & Titrimetric/iodimetric \\
Anthocyanin, mg/l & 26.44 & pH differential method \\
Calorie, kcal & 27.71 & \\
Calcium, mg/l & 167.10 & Atomic Absorption \\
& & Spectroscopy \\
\hline
\end{tabular}

aAll methods are based on the Indonesian National Standard SNI 01-2891-1992 (8).

Table II. Baseline physiological parameters of the subjects $(n=30)$.

\begin{tabular}{|c|c|c|}
\hline Characteristics & $\mathrm{n}(\%)$ & $\begin{array}{c}\text { Mean } \pm \text { standard } \\
\text { deviation }\end{array}$ \\
\hline Age, years & & $39.33 \pm 9.18$ \\
\hline $21-40$ & $14(47)$ & \\
\hline$>41$ & $16(53)$ & \\
\hline Sex & & - \\
\hline Male & $17(56.7)$ & \\
\hline Female & $13(43.3)$ & \\
\hline Body mass index & & $24.41 \pm 3.48$ \\
\hline Normal & $18(60)$ & \\
\hline Overweight & $10(33)$ & \\
\hline Obese & $2(7)$ & \\
\hline Abdominal circumference & & $84.23 \pm 9.44$ \\
\hline Systolic blood pressure & & $113.00 \pm 9.79$ \\
\hline Diastolic blood pressure & & $79.67 \pm 7.53$ \\
\hline \multicolumn{3}{|l|}{ Education } \\
\hline Secondary & $14(46.6)$ & \\
\hline Higher education & $16(53.3)$ & \\
\hline $\begin{array}{l}\text { Exercise or other physical } \\
\text { activity }\end{array}$ & $21(70)$ & \\
\hline \multicolumn{3}{|l|}{ Smoking } \\
\hline Yes & $7(23.3)$ & \\
\hline No & $23(76.7)$ & \\
\hline
\end{tabular}

Study design and preparation. The present study was a quasi-experimental study with a pre-post design. A total of 30 healthy subjects were treated with $200 \mathrm{ml}$ HSB each morning and evening for 30 consecutive days. Every week the subjects were asked to perform physical activity by following the Young Men's Christian Association step test $(10,11)$. Urine and blood samples were taken before (day 0) and after completion of the intervention (day 30) at 8 am prompt by the clinicians 
Table III. Pre- and post-physiological parameters of the subjects $(n=30)$.

\begin{tabular}{|c|c|c|c|}
\hline Physiological parameter & Mean & $\mathrm{t} / \mathrm{Z}$ & P-value \\
\hline Body mass index, $\mathrm{kg} / \mathrm{m}^{2}$ & & $0.74^{\mathrm{c}}$ & 0.338 \\
\hline Pre & 24.4 & & \\
\hline Post & 24.1 & & \\
\hline Abdominal circumference, $\mathrm{cm}$ & & $3.004^{\mathrm{c}}$ & $0.005^{\mathrm{b}}$ \\
\hline Pre & 84.2 & & \\
\hline Post & 81.8 & & \\
\hline Systolic blood pressure, $\mathrm{mmHg}$ & & $-2.094^{\mathrm{d}}$ & $0.036^{\mathrm{a}}$ \\
\hline Pre & 113 & & \\
\hline Post & 108.3 & & \\
\hline Diastolic blood pressure, $\mathrm{mmHg}$ & & $-2.988^{d}$ & $0.030^{\mathrm{a}}$ \\
\hline Pre & 77.3 & & \\
\hline Post & 73.2 & & \\
\hline Cholesterol levels, mg/dl & & $-0.229^{c}$ & 0.821 \\
\hline Pre & 191.2 & & \\
\hline Post & 191.9 & & \\
\hline Low density lipoprotein levels, mg/dl & & $-1.176^{c}$ & 0.249 \\
\hline Pre & 129.8 & & \\
\hline Post & 133.5 & & \\
\hline High density lipoprotein levels, mg/dl & & $-2.440^{\mathrm{d}}$ & $0.015^{\mathrm{a}}$ \\
\hline Pre & 47 & & \\
\hline Post & 49.5 & & \\
\hline Triglyceride levels, mg/dl & & $1.127^{\mathrm{c}}$ & 0.269 \\
\hline Pre & 114.3 & & \\
\hline Post & 107.4 & & \\
\hline Very low density lipoprotein levels, mg/dl & & $-0.411^{\mathrm{d}}$ & 0.681 \\
\hline Pre & 22.8 & & \\
\hline Post & 21.4 & & \\
\hline
\end{tabular}

${ }^{\mathrm{a}} \mathrm{P}<0.05,{ }^{\mathrm{b}} \mathrm{P}<0.01$. ${ }^{\mathrm{c}}$ Paired t-test; ${ }^{\mathrm{d}}$ Wilcoxon test. $\mathrm{t}$, used for testing the mean of one population against a standard or comparing the means of two populations; $\mathrm{Z}$, used for testing the proportion of a certain characteristic vs. a standard proportion, or comparing the proportions of two populations.

at the Health Technical Unit of Universitas Padjadjaran. The subjects were asked to fast for $10 \mathrm{~h}$ prior to collection.

Measurement of physiological parameters pre and post-treatment with HSB. Anthropometry data of the subjects: Height, weight and abdominal circumferences, were measured, as they represent the diagnostic criteria for obesity. The subjects were advised to wear light clothing and to take off their shoes before the measurement (12).

BMI for each participant was calculated based on the body weight $(\mathrm{kg})$ and height $(\mathrm{cm})$ using an online BMI calculator (nhlbi.nih.gov/health/educational/lose_wt/BMI/bmi-m.htm).

SBP and DBP. SBP and DBP were measured using a sphygmomanometer and stethoscope based on the American Heart Association's recommendation with three replicates per reading (13).

Urine collection and analysis. Overnight urine was collected and analyzed as described previously (14-16). The subjects were given direct instructions regarding the morning urine collecting procedure. The first few drops of the urine were discarded, and the collected urine sample was stored in sealed tubes. The urine samples were analyzed qualitatively using urinalysis reagent strips (cat. no. 006T250; Ultimed Products) to determine leukocyte counts, nitrite levels, urobilinogen levels, protein content, $\mathrm{pH}$, blood, ketones, specific gravity, bilirubin and glucose levels.

Biochemical analyses. Blood samples were taken by a clinician. The blood was placed in $\mathrm{K}_{2}$ EDTA BD vacutainer plastic blood collection tubes (Thermo Fisher Scientific, Inc.). Plasma was separated by centrifuging at 2,040 x g for $15 \mathrm{~min}$ and stored at $-20^{\circ} \mathrm{C}$ until required. The lipid profile was measured by enzymatic assays using an ARCHITECT c4000 clinical chemistry analyzer (Abbott Pharmaceutical Co. Ltd.).

Statistical analysis. A Shapiro-Wilk test for normality was used and data are presented as the mean \pm standard deviation. Data were compared using a paired t-test or Wilcoxon test as 
based on the normality of distribution in SPSS version 13.0 (SPSS, Inc.). $\mathrm{P}<0.05$ was considered to indicate a statistically significant difference.

\section{Results and Discussion}

Proximate analysis, and determination of vitamin $C$ and anthocyanin content in the HSB. The nutritional properties (proximate, vitamin C and anthocyanin) of HSB are presented in Table I. HSB has been shown to contain high calcium levels, a moderate amount of anthocyanin, and a small amount of protein, fat, carbohydrate and vitamin C.

Thepresence of anthocyaninindried roselle calyces has been reported previously $(17,18)$. Moreover, the vitamin C content was also confirmed (18-20). Delphinidin-3-sambubioside, cyanidin-3-sambubioside, delphinidin-3-glucoside and cyanidin-3-glucoside are four anthocyanins that have been shown to be present in the $H$. sabdariffa calyces and are hypothesized to play a role in its antioxidant property $(21,22)$.

It was reported that anthocyanins, due to their phenolic structure, function as an antioxidant via different mechanisms. Anthocyanins capture free radicals, inhibit xanthine oxidase and chelate metal ions (23). The phenolic moiety in the anthocyanins molecule contributes to the transfer of a proton to a free radical, eventually regenerating the acyl glycerol molecule, and stopping the oxidation reaction (24). The substitution of hydroxyl with sugars in anthocyanins molecule reduces xanthine oxidase activity. Moreover, the planarity of aromatic rings of anthocyanins, (the B ring that is connected by conjugation to $\mathrm{A}$ and $\mathrm{C}$ rings) may be responsible for this inhibitory effect (25).

Characteristics of the subjects and the baseline physiological parameters (pre-treatment with HSB). The subjects, aged 21-55 years, with a BMI between 18-30, were recruited in the present study. Of these, 7 of the subjects $(23.3 \%)$ were smokers, and none consumed alcohol; 18 subjects $(60 \%)$ had a normal BMI, and the average abdominal circumference was $84.23 \pm 9.44 \mathrm{~cm}$. The BP of the subjects was in the normal range. Additionally, 21 of the subjects (70\%) confirmed their weekly exercise, such as walking and biking, or other physical activity (Table II).

The subjects were confirmed healthy by a physician's examination and urinalysis at the Health Technical Unit of Universitas Padjadjaran (unpad.ac.id/universitas/fasilitas/kesehatan/). Electrocardiographic examination of the 30 healthy subjects (encoded as R1 to R30) revealed normal heart condition.

The color (colorless to pale yellow) and $\mathrm{pH}$ of urine of the subjects ranged between 5.0-6.5 (the mean $\mathrm{pH}$ value was 6.07), which was considered normal. One subject (R20) had a high leucocyte (white blood cells, WBC) number in the urine. The presence of abnormal of WBC counts was also detected in the urine of 3 subjects (R7, R8 and R16), which was likely associated with inflammation of the urinary tract or the use of steroid drugs (16). Moreover, no erythrocytes, nitrites, ketones, bilirubin or glucose were detected in the urine of any of the subjects.

Physiological parameters of the subjects post-treatment with $H S B$. Daily two-meal consumption (morning and evening) of $200 \mathrm{ml} \mathrm{HBS}$ for 30 consecutive days, significantly lowered the
Table IV. Pre- and post-urinalysis parameters $(\mathrm{n}=30)$.

\begin{tabular}{lccc}
\hline Physiological parameter & Mean & $\mathrm{t} / \mathrm{Z}^{\mathrm{a}}$ & $\mathrm{P}$-value \\
\hline White blood cell count & & -1.054 & 0.292 \\
Pre & 23.67 & & \\
Post & 6.61 & & \\
Nitrite & & 0 & 1 \\
Pre & 0 & & \\
Post & 0 & & \\
Urobilinogen & & 0 & \\
Pre & 0.2 & & \\
Post & 0.2 & & \\
Protein content & & -1.508 & 0.132 \\
Pre & 6.96 & & \\
Post & 4.29 & & \\
pH & & -1.794 & 0.073 \\
Pre & 6.06 & & \\
Post & 5.86 & & \\
Red blood cell count & & 0 & 1 \\
Pre & 0 & & \\
Post & 0 & & \\
Specific gravity & & -0.617 & 0.537 \\
Pre & 1.017 & & \\
Post & 1.018 & & \\
Ketones & & 0 & 1 \\
Pre & 0 & & \\
Post & 0 & & \\
Bilirubin & & & \\
Pre & 0 & & \\
Post & 0 & & \\
Glucose & & & \\
Pre & & & \\
Post & 0 & & \\
\hline
\end{tabular}

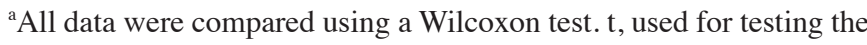
mean of one population against a standard or comparing the means of two populations; $\mathrm{Z}$, used for testing the proportion of a certain characteristic vs. a standard proportion, or comparing the proportions of two populations.

abdominal circumference $(\mathrm{P}=0.005)$ and both $\mathrm{SBP}$ and $\mathrm{DBP}$ $(\mathrm{P}=0.036$ and $\mathrm{P}=0.030$, respectively) of healthy adults. There was an increase in the levels of high-density lipoproteins (47.0 to $49.5 \mathrm{mg} / \mathrm{dl} ; \mathrm{P}=0.015$ ). However, the total cholesterol (191.2 to $191.9 \mathrm{mg} / \mathrm{dl} ; \mathrm{P}=0.821$ ) and low density lipoprotein levels (129.8 to $133.5 \mathrm{mg} / \mathrm{dl} ; \mathrm{P}=0.249$ ) were slightly increased, although not significantly. A lower level of triglycerides (114.3 to $107.4 \mathrm{mg} / \mathrm{dl} ; \mathrm{P}=0.269$ ) and very low-density lipoprotein (VLDL) (22.8 to $21.4 \mathrm{mg} / \mathrm{dl} ; \mathrm{P}=0.681$ ) was observed (Table III). No significant differences were observed in the BMI (Table III) or the urinalysis parameters (Table IV).

These findings are in line with previous similar studies in 25 British male participants with 1-10\% risk of cardiovascular disease (2), in 65 non-smoking pre- to mild hypertensive 
patients (70\% Caucasians, aged 30-70 years) (3), in 60 Iranian diabetic patients with mild hypertension (5) and in 32 African male subjects (aged 21-32) (6). Interestingly, a H. sabdariffa isotonic drink was reported to be capable of increasing the physical fitness index of healthy respondents (25).

In conclusion, healthy subjects treated with $200 \mathrm{ml}$ roselle calyx beverage each morning and evening for 30 consecutive days resulted in an increase in HDL levels. A significant decrease of both SBP and DBP and the abdominal circumference of the subject was also noticed. However, the total cholesterol and LDL levels were slightly increased, although not significantly. Lower levels of triglycerides and VLDL were observed. No significant difference was detected in the BMI and the urinalysis parameters. H. sabdariffa L. may thus prospectively improve the health status of subjects. No serious adverse effects were observed during this trial. However, the data of this study is still limited due to the lack of a normal control group, the heterogeneity of the subjects and the small sample size. Nonetheless, the present study provides evidence of the value of $H$. sabdariffa $\mathrm{L}$ for healthy subjects.

\section{Acknowledgements}

We would like to thank Professor Tri Hanggono Achmad, the Rector of Universitas Padjadjaran via the Directorate of Research and Community Engagement for facilitating this work by granting the Academic-Leadership Grant (ALG) 2019 of Universitas Padjadjaran.

\section{Funding}

This work was funded by the Academic-Leadership Grant (grant no. 1373i/UN6.O/LT/2019).

\section{Availability of data and materials}

The datasets used and/or analyzed during the present study are available from the corresponding author on reasonable request.

\section{Author's contributions}

$\mathrm{AD}$ and $\mathrm{JL}$ were principally responsible for the conception and design of the study. SAS and LL supervised and monitored the recruitment and selection of the subjects. SR and AA participated in the preparation of the roselle beverage and measurement of other clinical parameters. AD, JL and SAS contributed equally to the acquisition, and interpretation of the reported data. AD, JL and LL contributed to the processing and analysis of the data. JL contributed to the writing, and revising of the manuscript. All authors read and approved the final manuscript. SR and AA confirm the authenticity of all the raw data.

\section{Ethics approval and consent to participate}

Written informed consent was obtained from all the participants. The Research Ethical Committee of Universitas Padjadjaran, Indonesia approved the procedures (approval no. 35/UN6.C.10/PN/2018). The Declaration of Helsinki (2000) and the applicable national standards as they relate to the involvement of human subjects in the research were enforced in the design and conduct of the present study.

\section{Patient consent for publication}

Not applicable.

\section{Competing interests}

The authors declare that they have no competing interests.

\section{References}

1. Susilawati Y, Rahmatullah TS, Muhtadi A, Sofyan FF and Tjitraresmi A: Aktivitas antihipertensi ekstrak kering terstandarisasi kelopak bunga rosela (Hibiscus sabdariffa L.) hasil produksi skala pilot. J Sains Kes 1: 554-560, 2018.

2. Abubakar SM, Ukeyima MT, Spencer JPE and Lovegrove JA: Acute effects of Hibiscus sabdariffa calyces on postprandial blood pressure, vascular function, blood lipids, biomarkers of insulin resistance and inflammation in humans. Nutrients 11: 341, 2019

3. McKay DL, Chen CY, Saltzman E and Blumberg JB: Hibiscus sabdariffa L. tea (tisane) lowers blood pressure in prehypertensive and mildly hypertensive adults. J Nutr 140: 298-303, 2010.

4. Herrera-Arellano A, Miranda-Sánchez J, Avila-Castro P, HerreraAlvarez S, Jiménez-Ferrer JE, Zamilpa A, Román-Ramos R, Ponce-Monter $\mathrm{H}$ and Tortoriello J: Clinical effects produced by a standardized herbal medicinal product of Hibiscus sabdariffa on patients with hypertension. A randomized, double-blind, lisinopril-controlled clinical trial. Planta Med 73: 6-12, 2007.

5. Mozaffari-Khosravi H, Jalali-Khanabadi BA, AfkhamiArdekani M, Fatehi F and Noori-Shadkam M: The effects of sour tea (Hibiscus sabdariffa) on hypertension in patients with type II diabetes. J Hum Hypertens 23: 48-54, 2009.

6. Tazoho G, Gouado I, Ndomou M, Bonsi S, Wamba Y and Agbor E: Clinical, hematological and biochemical health benefit effects of Hibiscus sabdariffa Lin dried calyces beverage in human. Food Nutr Sci 7: 383-395, 2016.

7. Salami SO and Afolaya AJ: Suitability of roselle-hibiscus sabdariffa L. as raw material for soft drink production. J Foof Quality 2020: 8864142, 2020.

8. Indonesian National Standard SNI 01-2891-1992. Uji Makanan dan Minuman.Badan Standardisasi Nasional (BSN), Jakarta, Indonesia.

9. Giusti MM and Wrolstad RE: Characterization and measurement of anthocyanins by UV-Visible Spectroscopy. Current Protocols in Food Analytical Chemistry F1.2.1.-F1.2.13, 2001.

10. Beutner F, Ubrich R, Zachariae S, Engel C, Sandri M, Teren A and Gielen S: Validation of a brief step-test protocol for estimation of peak oxygen uptake. Eur J Prev Cardiol 22: 503-512, 2015.

11. Teren A, Zachariae S, Beutner F, Ubrich R, Sandri M, Engel C, Löffler $\mathrm{M}$ and Gielen S: Incremental value of veterans specific activity questionnaire and the YMCA-step test for the assessment of cardiorespiratory fitness in population-based studies. Eur J Prev Cardiol 23: 1221-1227, 2016.

12. Casadei K and Kiel J: Anthropometric Measurement. StatPearls Publishing, Treasure Island, FL, 2021.

13. Black DR, Coster DC and Paige SR: Physiological health parameters among college students to promote chronic disease prevention and health promotion. Prev Med Rep 7: 64-73, 2017.

14. Mutakin M, Irawan RM, Ratnasari T, Saraswati PI, Salma SP, Iskartama MJ, Megantara S and Levita J: Urinary sodium/potassium ratio and the effect of diet salt to blood pressure. SAJ Pharma Pharmacol 5: 301, 2018.

15. Corder CJ, Rathi BM, Sharif S and Leslie SW: 24-Hour Urine Collection. StatPearls Publishing, Treasure Island, FL, 2021.

16. Milani DAQ and Jialal I: Urinalysis. StatPearls Publishing, Treasure Island, FL, 2021.

17. Wu HY, Yang KM and Chiang PY: Roselle anthocyanins: Antioxidant properties and stability to heat and $\mathrm{pH}$. Molecules 23: 1357, 2018.

18. Mgaya-Kilima B, Remberg SF, Chove BE and Wicklund T: Physiochemical and antioxidant properties of roselle-mango juice blends; effects of packaging material, storage temperature and time. Food Sci Nutr 3: 100-109, 2015. 
19. Bamishaiye EI, Olayemi FF and Bamishaiye OM: Effects of boiling time on mineral and vitamin c content of three varieties of Hibiscus sabdriffa drink in Nigeria. World J Agric Sci 7: 62-67, 2011.

20. Aina JO and Shodipe AA: Colour stability and vitamin C retention of roselle juice (Hibiscus sabdariffa $\mathrm{L}$ ) in different packaging materials. Nutr Food Sci 36: 90-95, 2006.

21. Amor BB and Allaf K: Impact of texturing using instant pressure drop treatment prior to solvent extraction of anthocyanins from Malaysian Roselle (Hibiscus sabdariffa). Food Chem 115: 820-825, 2009.

22. Cisse M, Vaillant F, Kane A, Ndiaye O and Dornier M: Impact of the extraction procedure on the kinetics of anthocyanin and colour degradation of roselle extracts during storage. J Sci Food Agri 92: 1214-1221, 2012.
23. Reis JF, Monteiro VV, de Souza Gomes R, do Carmo MM, da Costa GV, Ribera PC and Monteiro MC. Action mechanism and cardiovascular effect of anthocyanins: A systematic review of animal and human studies. J Transl Med 14: 315, 2016.

24. Byrne JA, Grieve DJ, Bendall JK, Li JM, Gove C, Lambeth JD, Cave AC and Shah AM: Contrasting roles of NADPH oxidase isoforms in pressure-overload versus angiotensin II-induced cardiac hypertrophy. Circ Res 93: 802-805, 2003.

25. Ariviani S, Fauza G and Pawestri C: Development of dark roselle (Hibiscus sabdariffa) as potentially antioxidant isotonic drinks and its capability to improve physical fitness. Agritech 37 : 386-394, 2017.

This work is licensed under a Creative Commons Attribution-NonCommercial-NoDerivatives 4.0 International (CC BY-NC-ND 4.0) License. 